Canadian University Music Review

Canadian University Music Review

Revue de musique des universités canadiennes

\title{
Robin Elliott and Gordon E. Smith, eds. 2001. István Anhalt: Pathways and Memory. Montreal: McGill-Queen's University Press, xx, 425 pp. ISBN 0- 7735-2102-X (paperback)
}

\section{J. Drew Stephen}

Volume 24, numéro 1, 2003

URI : https://id.erudit.org/iderudit/1014678ar

DOI : https://doi.org/10.7202/1014678ar

Aller au sommaire du numéro

Éditeur(s)

Canadian University Music Society / Société de musique des universités canadiennes

ISSN

0710-0353 (imprimé)

2291-2436 (numérique)

Découvrir la revue

Citer ce compte rendu

Stephen, J. D. (2003). Compte rendu de [Robin Elliott and Gordon E. Smith, eds. 2001. István Anhalt: Pathways and Memory. Montreal: McGill-Queen's University Press, xx, 425 pp. ISBN 0- 7735-2102-X (paperback)]. Canadian

University Music Review / Revue de musique des universités canadiennes, 24(1), 131-133. https://doi.org/10.7202/1014678ar

All Rights Reserved (C) Canadian University Music Society / Société de musique des universités canadiennes, 2005
Ce document est protégé par la loi sur le droit d'auteur. L'utilisation des services d'Érudit (y compris la reproduction) est assujettie à sa politique d'utilisation que vous pouvez consulter en ligne.

https://apropos.erudit.org/fr/usagers/politique-dutilisation/ 
Hyer, Brian. 1995. "Reimag(in)ing Riemann." Journal of Music Theory 39, no. 1 (Spring): 101-38.

Lewin, David. 1982. "A Formal Theory of Generalized Tonal Functions." Journal of Music Theory 26, no. 1 (Spring): 23-60.

Glen E. Ethier

Robin Elliott and Gordon E. Smith, eds. 2001. István Anhalt: Pathways and Memory. Montreal: McGill-Queen's University Press. xx, 425 pp. ISBN 07735-2102-X (paperback).

István Anhalt is a remarkably complex individual with a seemingly unending range of interests and abilities. This is due, partly, to his insatiable intellectual curiosity, but perhaps also to the many ways in which he was formed by, and represents the ideals of, an earlier era. Despite the startling modernity of his compositions and a willingness to embrace new methods and techniques, he is also a craftsman who is able to speak forcibly to audiences through his eloquence and sincerity of expression. He was an early pioneer in the field of electroacoustic music, yet he continues to correspond with hand-written letters. $\mathrm{He}$ is a composer, a poet, and the highly perceptive author of analytical texts. His works embrace topics that cover the entire range of human experience. In many instances they deal with complex issues which are not only moving, but which challenge the listener intellectually. By addressing the rich diversity of Anhalt's life and creativity, István Anhalt: Pathways and Memory presents an engaging portrait of its subject. A fitting tribute to one of Canada's most profound composers, it is also a landmark in Canadian music studies.

The book contains contributions from ten authors (including Anhalt himself) that are organized into four large thematic sections. In the first, "Life Lines," the editors, Robin Elliott and Gordon Smith, reconstruct the biographical details of Anhalt's life. These include his family background and musical education in Hungary, his harrowing experiences as a Jew during World War II, his emigration from Europe to Canada as a young man, and his years in Montreal and Kingston as a composer, teacher, and administrator. Throughout, Anhalt's creative instincts as a composer and writer are woven into the context of his life experiences, reinforcing the authors' thesis that the two are integrally linked. The second section, "Compositions," provides an examination of Anhalt's musical works in several genres. Robin Elliott discusses the instrumental and solo works, John Beckwith covers the orchestral works, and David Keane the electroacoustic repertoire. In an additional chapter, William Benjamin traces the development of Anhalt's stylistic maturation in two major orchestral works: the Symphony of 1958 and SparkskrapS of 1987. The third section, "Writings," deals with Anhalt's various relationships to written texts. Carl Morey explores Anhalt's use of text in his musical works and his increasing reliance on his own texts rather than on other sources. Austin Clarkson discusses Anhalt's analytical writings with particular reference to Alternative Voices (1984), Anhalt's pioneering study of extended vocal techniques in 
music of the 1960s and 1970s. Helmut Kallmann describes and indicates the significance of the large collection of papers and documentation in the Anhalt fonds at the National Library of Canada. Spanning Anhalt's entire life, the collection holds enormous potential for future researchers. This section concludes with composer George Rochberg's highly personal "reflections and ruminations, thoughts and feelings" (p. 355) on his forty-year friendship with Anhalt. The final section, "In Anhalt's Voice," is given over to Anhalt himself and is mostly devoted to his operatic works. Although originating from a single author, the chapters in this section-they include discussions of several operatic works, a "Dialogue with the Self," and the libretto to Anhalt"s fourth opera-are as varied in approach and style as are the chapters in the rest of the book.

The range of contributors includes Anhalt's long-time friends, colleagues, and former students. Clearly, the choice of authors was the result of careful consideration by the editors, and they are to be commended for drawing together such a diverse yet accomplished group of commentators. Rather than presenting a disparate view of Anhalt and his music, the individual voices and viewpoints merge to present a complex yet coherent picture. Many of the works, events, and themes in Anhalt's life are discussed at multiple points in the book, yet the result is not repetitious. Instead, the multiplicity of contexts and interpretations leads to a richly layered understanding of them. The scope of the contributions is equally impressive. George Rochberg provides by far the most personal account: in discussing his kinship with Anhalt, formed in spite of the profound differences of their personal experiences and outlooks, he reveals much about human qualities of both men. William Benjamin's "Alternatives of Voice," by contrast, is a detailed and penetrating analysis of the maturation of Anhalt's compositional style. Spanning 143 pages (over a quarter of the book's entire length), it is an exceptional, albeit challenging, evaluation of Anhalt's compositional processes. The inclusion of Anhalt's own writings adds more than just a personal touch. After reading so much about him, it is fascinating to encounter him in his own words and thoughts. As a writer, Anhalt emerges fully as articulate and eloquent as all previous descriptions of him suggest he should be.

Given the obvious thoroughness with which the material in this book has been researched and prepared, I was surprised by the absence of a discography in the appendix. Although there is a comprehensive list of Anhalt's writings and compositions, there is no mention of any recordings. The problem, it seems, is not due to editorial oversight, but rather is indicative of a disturbing lack of commercially available recordings of Anhalt's music-an issue raised more than once in the book. Many of his major works have not been recorded, and, in some cases-the Symphony of Modules for example-they even remain unperformed. While the reader is compensated for the lack of audio recordings by the rich and vivid verbal descriptions of Anhalt's music throughout the text, these alone cannot replace the experience of hearing the music performed. Beckwith ends his chapter on the orchestral works with the observation that 
the "splendid trio of orchestral works from late-period Anhalt" would fit perfectly on a seventy-minute audio CD to provide "a fine gift to future generations" (p. 130). Benjamin, in preparing his analysis of Anhalt's symphony, cites "a remote descendant of a master tape of a 1960 performance of the Toronto Symphony under Walter Susskind" (p. 303). Although this recording is apparently inadequate for commercial release, one laments the fact that we, as readers, are not able to consult it while reading Benjamin's analysis. The possibility of listening to this and other compositions would certainly allow for a deeper understanding of the individual works discussed in the book. It would also lead to a greater overall appreciation of Anhalt's significance as a composer.

With the recent release of a two-CD set devoted to Anhalt's music on Centredisc's Canadian Composers Portraits series, the situation has improved slightly. ${ }^{1}$ In addition to a remastered recording of Foci from 1969, the disc also contains a live recording of The Tents of Abraham, a new work that was composed after the publication of Pathways and Memory. ${ }^{2}$ Still, there are many more works that could and should be available on disc. The value of Pathways and Memory is that it situates Anhalt at the forefront of contemporary composers, not only in Canada, but internationally. One hopes that it will foster interest in Anhalt's music and instigate future performances and recordings. The details of Anhalt's life and his compositional style have been presented thoroughly and eloquently. His importance as a composer has been argued with conviction. His music needs to be heard.

\section{REFERENCE}

Anhalt, István. 1984. Alternative Voices: Essays on Contemporary Vocal and Choral Composition. Toronto: University of Toronto Press.

J. Drew Stephen

Theodor W. Adorno. 2002. Essays on Music. Selected, with introduction, commentary, and notes by Richard Leppert. Trans. Susan H. Gillespie et al. Berkeley: University of California Press. Bibliography, 743 pp. ISBN 0-52023159-7 (paperback).

Happiness for Adorno was social. Personal happiness in the face of general social unhappiness (injustice) was false by definition; it resided in the realm of social privilege, a socio-psychic gated community (p. 514).

It is wrong to say that Adorno chose not to like popular music and jazz. Truth be known, he was prevented from liking it by a certain logic in his scholarly

1CMCCD 10204. The two-CD set includes an audio CD of Anhalt's compositions and a full-length documentary on the composer's life and music.

2Robin Elliott's review of the premiere performance of The Tents of Abraham is published in The Institute for Canadian Music Newsletter 2, no. 2 (May 2004): 12. An online edition can be accessed at http://www.utoronto.ca/icm/newsletter.html (PDF). 